Sustainable Development of Small Island Tourism Resort: A Case of Egang-Egang Resort Bum-Bum Island Semporna

Wan Azfarozza Wan Athmar, Abdul Rahim Ridzuan, Mohd Hilmi Bakar, Nor Raihan Abu Bakar, Muhammad Azril Izuan Ramlan, Noorazura Durani, Akmal Adanan, Mohamad Idham Md Razak \& Mohd Hafiz Hanafiah

To Link this Article: http://dx.doi.org/10.6007/IJARBSS/v11-i5/9758

DOI:10.6007/IJARBSS/v11-i5/9758

Received: 01 March 2021, Revised: 20 April 2021, Accepted: 19 May 2021

Published Online: 29 May 2021

In-Text Citation: (Athmar et al., 2021)

To Cite this Article: Athmar, W. A. W., Ridzuan, A. R., Bakar, M. H., Bakar, N. R. A., Muhammad Azril Izuan Ramlan, Noorazura Durani, Akmal Adanan, M. I. M. R., \& Hanafiah, M. H. (2021). Sustainable Development of Small Island Tourism Resort: A Case of Egang-Egang Resort Bum-Bum Island Semporna. International Journal of Academic Research in Business and Social Sciences, 11(5), 827-841.

Copyright: (c) 2021 The Author(s)

Published by Human Resource Management Academic Research Society (www.hrmars.com)

This article is published under the Creative Commons Attribution (CC BY 4.0) license. Anyone may reproduce, distribute, translate and create derivative works of this article (for both commercial and non-commercial purposes), subject to full attribution to the original publication and authors. The full terms of this license may be seen at: http://creativecommons.org/licences/by/4.0/legalcode

Vol. 11, No. 5, 2021, Pg. 827 - 841

Full Terms \& Conditions of access and use can be found at http://hrmars.com/index.php/pages/detail/publication-ethics 


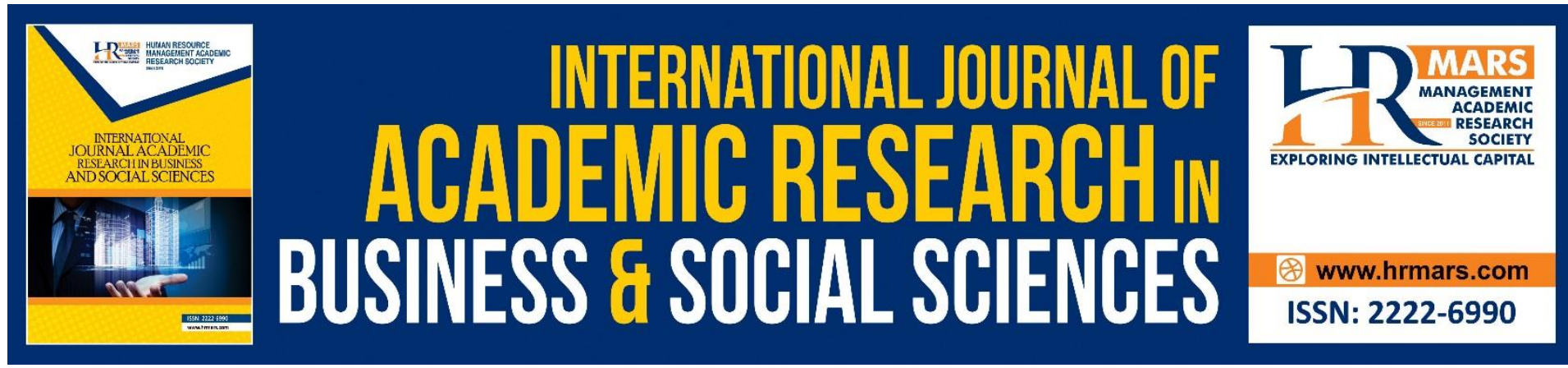

\title{
Sustainable Development of Small Island Tourism Resort: A Case of Egang-Egang Resort Bum-Bum Island Semporna
}

\author{
Wan Azfarozza Wan Athmara, Abdul Rahim Ridzuan ${ }^{\text {b1 }}$, Mohd \\ Hilmi Bakara, Nor Raihan Abu Bakara, Muhammad Azril Izuan \\ Ramlanc, Noorazura Durania, Akmal Adanan', Mohamad Idham \\ Md Razak ${ }^{b}$ \& Mohd Hafiz Hanafiahe
}

${ }^{a}$ Faculty of Communication and Media Studies, Universiti Teknologi MARA, Melaka, ${ }^{b}$ Faculty of Business and Management, Universiti Teknologi MARA, Melaka, 'Faculty of

Communication and Media Studies, Universiti Teknologi MARA, Negeri Sembilan, dFaculty of Hotel and Tourism Management, Universiti Teknologi MARA, Melaka, ${ }^{\mathrm{e} F a c u l t y}$ of Hotel and

Tourism Management, Universiti Teknologi MARA, Selangor

\begin{abstract}
Tourism development is crucial in small island economic developments, but such activities involve trade-offs between the benefits and environmental, social and cultural detriment. Sustainability is one of the critical factors determining tourism development success promoting the balance between protecting the environment, maintaining cultural integrity, establishing social justice, and promoting economic benefits. This paper explores how relevant stakeholder groups perceive sustainable tourism development in the Egang-egang Resort Bum-Bum Island Semporna. A survey was conducted on the locals residing within the area of Egang Egang Water Chalet (EEWC). The study discovered that EEWS operations produce positive impacts on the sustainability of economic, social and environmental factors. Our findings show that the local community is interested in the wider aspects of tourism development, which require careful management of social and environmental resources.
\end{abstract}

Keywords: Sustainable Tourism, Economic, Social, Environmental

\section{Introduction}

Tourism is one of the main sources of income to many countries, thus contributing to economic development. This is especially evident in developing countries (Goffi, Cucculelli, \& Masiero, 2019; Sokhanvar, Çiftçioğlu, \& Javid, 2018). As tourism is considered such, most government has taken a giant leap through the tourism industry's mass expansion, exploiting their natural and heritage products (Risteskia, Kocevskia, \& Arnaudov, 2012). However, as much as tourism development contributes to the economic, there are raising concerns about its sustainability (Hall, 2019). Most researchers claimed that tourism development, especially

${ }^{1}$ Corresponding author: Rahim670@uitm.edu.my 
in island tourism, will inevitably lead to some signs of imbalance, including excessive coastal development and the destruction of ecological resources (Bojanic \& Lo, 2016; Eusébio, Vieira, \& Lima, 2018; Hanafiah, Jamaluddin, \& Zulkifly, 2013). Besides, such development may affect the traditional community system and gradually create an imbalance in the locals' lifestyles (Sinclair-Maragh \& Gursoy, 2015).

Sustainable development is a highly quoted actionable example of enhancing the quality of the community and the local community plays a pivotal role as the main stakeholder in tourism development (Hanafiah et al., 2013; Ling, Jakpar, Johari, Abdul Rani, \& Myint, 2011). Similarly, various researchers claimed that the success of tourism depends on the sustainable management of destination resources and stakeholders' participation in tourism planning and management (Bello, Carr, \& Lovelock, 2016; Jordan, Vogt, Kruger, \& Grewe, 2013; Khazaei, Elliot, \& Joppe, 2015). To understand the concept in terms of sustainable tourism, a deep understanding of community perception is crucial. The stakeholders' feedback can be used as a vital indicator in measuring the impact of sustainable tourism development towards the locals' economic, social and environment aspects (Kuščer \& Mihalič, 2019; Poudel, Nyaupane, \& Budruk, 2016). However, the main principle of community participation in tourism development has been proven difficult to achieve (Cárdenas, Byrd, \& Duffy, 2015).

Butler (1980) pointed out that tourism development is the series of stages through which destination evolves, involvement, development, consolidation, and stagnation and affects the local stakeholders. It is evident as opening a tourism spot in a new area means tapping the untapped nature, which may cause disruptions to the existing peace and the way of life of the locals (Butler, 1980; de Jager \& Nicolau, 2020; Oklevik et al., 2019). Thus, various research was done exploring local community attitudes towards tourism development, focusing on tourism appropriateness for the local communities (Hall \& Lew, 2009). Most tourism impact study utilised the Social Exchange Theory (SET), which is the theoretical framework for developing an understanding of local community attitudes towards tourism (Altinay \& Taheri, 2019; Nunkoo, 2016; Nunkoo \& Gursoy, 2012; Rasoolimanesh, Jaafar, Kock, \& Ramayah, 2015; Ward \& Berno, 2011)

The SET is widely utilised in various studies and most commonly accepted framework in explaining the residents' perception, reactions, and attitudes towards the development of tourism since it allows to capture a different perspective of residents based on the experience and psychological outcomes (Nunkoo \& Gursoy, 2012). The SET draws social interaction is an exchange of resources. It suggests that an individual is likely to engage in an exchange if they expect to benefit from materials, social and psychological aspects without incurring an unacceptable cost (Ward \& Berno, 2011). Various studies have utilised SET and verified the importance of residents' perception of tourism impacts influencing their support towards tourism development (Nunkoo, 2016; Rasoolimanesh et al., 2015). However, there is lack of agreement among the researchers in the literature regarding the measurement and the classification of residents' perception of the tourism impacts (Cárdenas et al., 2015).

Therefore, understanding and knowing the local community attitudes is the key to the success of tourism planning, especially in fragile destinations like islands. Besides, to ensure the success of the tourism planning, the involvement and participation of the local communities in the area are pertinent (Bello et al., 2016; Jordan et al., 2013). Hall and Lew (2009) recommend that development policies and action must be set in place in an attempt to keep the balance between tourism development costs and benefits in social, economic, and environment. This is due to tourism being greatly seen as a way to generate the economy, but it comes with 
conflicting effects on the social and environmental. Therefore, sustainable development in tourism would keep balancing the impact - ensuring conservation is taken into account whilst harvesting the monetary benefits.

The purpose of this study is to explore local community attitudes towards tourism development in Egang-egang Resort Bum-Bum Island Semporna. This study will particularly underscore the perceived tourism impact and attitudes from the current tourism development. The assessment will be based on three pillars: (i) economic impacts, (ii) social impacts and (iii) environmental impacts. This current study is in-line with Sustainability Development Goals (SGDs), focusing on EEWC development's impacts towards sustainability of its surroundings.

\section{Literature Review}

\section{Sustainable Tourism Development}

In recent years, sustainable development has become a significant issue affecting the tourism industry (Atkinson, Dietz, Neumayer, \& Agarwala, 2014; Blewitt, 2014; Sachs, 2015). The concept of sustainable development became popular because it made a promise to maintain a standard of living similar to what we have today, while at the same time recognising that we cannot continue to use the global environment as we did in the past (Ritchie, Goeldner, \& McIntosh, 2003). However, the concept of sustainable development is not new as it was coined years ago (Blewitt, 2014). When people began to pay attention to climate change, natural resource reduction and pollution in the late 1980s, the concept of sustainable development was recognised (Atkinson et al., 2014; Emas, 2015). Emas (2015) indicated that the key principle of sustainable development underlying all others is integrating environmental, social, and economic concerns into all aspects of decision making. Past literature has proven that sustainability's embedment expands beyond socio-cultural and environmental concerns (Kuhlman \& Farrington, 2010).

Numerous researchers have broadly integrates the sustainable concept in the perspective of tourism (Basiago, 1998; Berry \& Ladkin, 1997; Higgins-Desbiolles, 2018; Mihalic, 2016; Pan et al., 2018; Ritchie et al., 2003). Several researchers have proposed that sustainable tourism development involves enhancing the quality of life of the local society while fulfilling the needs of tourists (Mathew \& Sreejesh, 2017; Ridderstaat, Croes, \& Nijkamp, 2016; Uysal, Sirgy, Woo, \& Kim, 2016). The purpose of sustainable tourism is to make a balance between protecting the environment, maintaining cultural integrity, establishing social justice, and promoting economic benefits, meeting the needs of the host population in terms of improved living standards both in the short and long term (Higgins-Desbiolles, 2018; Mihalic, 2016). Sustainable tourism development requires long-term maintenance of the viability of highquality natural resources and human resources. According to Basiago (1998), besides the main actor (local community), there are three main pillars in determining tourism sustainability: economics, social, and environment impact. No matter what point of view is drawn, it can be concluded that in sustainable development, paying attention to a certain degree of harmony between tourism stakeholder and tourism development would ensure continuous ideal impact towards the community's quality of life (Mathew \& Sreejesh, 2017).

The tourism industry has the potential to contribute to sustainable development, particularly by job creation, including employment for women and marginalised groups (Cárdenas et al., 2015; Hall \& Lew, 2009; Marafa, 2008). However, tourism development, besides offering favourable economic impacts, many caused various consequences in regards to environmental and social issues. Marafa (2008) claimed that variety of recreation and leisure 
activities caused the environment are more vulnerable to human-induced impacts. In term of small island, uncontrolled visitation, overuse of beaches, degrading the beach conditions and destroying the flora and fauna are a few of negative impact from uncontrolled tourismd evelopment (Hanafiah et al., 2013; Ridderstaat et al., 2016). Therefore, it is vital for the local stakeholders, particularly residents, to involve in environmentally responsible behavior as a step in preserving natural resources and the environment. Such participation would allow a much balanced tourism development that take into consideration the impact of tourism development towards the local community's quality and way of life (Cárdenas et al., 2015; Mathew \& Sreejesh, 2017).

\section{Tourism Impacts}

Various studies have focused on the impacts of tourism and community perception on the impacts of tourism development (Andereck, Valentine, Knopf, \& Vogt, 2005; Peters, Chan, \& Legerer, 2018; Woo, Uysal, \& Sirgy, 2018; Wu, Kim, \& Wong, 2020). Most of the studies have proved that the community who perceive a personal benefit or more significant economic gain tend to have a positive perception towards the impacts of tourism development (Kuščer \& Mihalič, 2019; Ling et al., 2011; Peters et al., 2018). Maximising the positive impacts and minimising the potential negative impacts of tourism development become the goal among the community, official and the tourism industry. Thus, it is crucial to identify the possible impacts of tourism development. Crouch (1999) tabulate the major positive and negative impacts of the matter. Various tourism researchers have recognised that there are wideranging influences in terms of economic influence, socio-cultural influence, and natural influence (Ling et al., 2011; Mathew \& Sreejesh, 2017; Peters et al., 2018; Woo et al., 2018; Wu et al., 2020). Therefore, this study focuses on the three main elements of tourism impact: the economic, environmental and socio-cultural.

\section{Economic Impact}

The development of tourism creates employment opportunities, improves the living standards of communities, promotes and attracts investors to invest, and increases tourist destination communities' personal income (Basiago, 1998). Other recent research also claimed that the economic benefits are the most significant benefits of tourism development, and communities obtain benefits through tourism activities (Bojanic \& Lo, 2016; Sokhanvar et al., 2018). The economic impact of tourism development has become the subject of most studies because it is easier to measure. It is generally believed that tourism can generate substantial benefits and help solve economic problems (Budeanu, 2005; Gursoy, Ouyang, Nunkoo, \& Wei, 2019). Most of the studies done by previous researchers included assessments about the economic impact that residents may have on tourism development (Gursoy et al., 2019; Kuščer \& Mihalič, 2019; Ling et al., 2011). These studies recalled that the positive economic effects include increased employment opportunities, increased investment, improved living standards, and increased incomes (Sokhanvar et al., 2018). In contrast, the negative effects are hike in real estate, land, property, commodity and services prices (Bojanic \& Lo, 2016).

\section{Environmental Impact}

Although people usually think of tourism as a "clean industry", unfortunately it could cause serious damage to the environment (Budeanu, 2005; Canteiro, Córdova-Tapia, \& Brazeiro, 2018; Hall \& Lew, 2009). Most previous studies have revealed the positive impact of the 
economy on the community. However, these study reveal but most of the environmental impacts associated with tourist activities are adverse (Basiago, 1998; Hsieh \& Kung, 2013). Previous studies constantly review the positive impact of tourism on the development of tourism, which contributes to the protection of natural resources (Basiago, 1998; Hsieh \& Kung, 2013; Li, Yang, Liu, \& Zheng, 2014; Marafa, 2008) and improving the community's ecological environment in many ways (Aminian, 2012). However, studies have shown that the negative impact of tourism development on the environment vary. Researchers claimed air, water and soil pollution, noise pollution, loss of grassland, green space and deforestation and wastage (Budeanu, 2005; Canteiro et al., 2018; Hall \& Lew, 2009; Hsieh \& Kung, 2013; Li et al., 2014; Mathew \& Sreejesh, 2017; Peters et al., 2018) are the adverse environmental effect due to the uncontrolled tourism development.

\section{Social-cultural Impact}

The interaction between the visitor and the host is an important part of the visitor experience (Jovičić, 2011; Meimand et al., 2017; Sandeep \& Vinod, 2014). Researchers in the past have found that the development of tourism has had a positive and negative impact on the reception population of tourist destinations (Basiago, 1998; McCombes, Vanclay, \& Evers, 2015; Okech, 2010; Sandeep \& Vinod, 2014). The most frequently mentioned positive social impact of tourism development is that tourism development provides residents with more social and entertainment opportunities, improved service quality of tourism infrastructure and provide recreational opportunities for local communities (Basiago, 1998; Hanafiah et al., 2013; Piuchan, Chan, \& Kaale, 2018; Sandeep \& Vinod, 2014). On the other hand, there are usual recurring negative social impacts on tourist destination communities such as the increase in community traffic, crowding of public spaces and facilities, and the increase in social problems; crime, drug abuse, prostitution, alcoholism, gambling, smuggling (Jovičić, 2011; Meimand et al., 2017; Sandeep \& Vinod, 2014).

\section{Community Perceptions}

Many researchers have conducted perceptual studies on the impact of tourism development from local communities' perspectives (Budeanu, 2005; Canteiro et al., 2018; Cottrell \& Vaske, 2006; Li et al., 2014; Mathew \& Sreejesh, 2017; Woo et al., 2018). According to the research of Cottrell and Vaske (2006), the most accurate factor in the assessment of tourism impact is the intimacy and affinity of the community towards tourism development. In addition, the development of tourism and the interaction with tourists are factors that directly affect the community support (Hanafiah et al., 2013; Nunkoo \& Gursoy, 2012). Moreover, understanding the community perspective may help the government plan and draft policies to minimise the possible negative impacts of tourism development and maximise its benefits, leading to community support towards tourism development (Deery, Jago, \& Fredline, 2012; Hall \& Lew, 2009; McCombes et al., 2015). Consequently, such understanding would influence the success and failure of tourism development in the future.

Tourism academics have also investigated some feature detail about tourism contributions to various aspects of residents' quality of life in the tourist destination (Kim, Uysal, \& Sirgy, 2013; Uysal et al., 2016). Notably, various researchers claim the perceived impacts of tourism development on the residents of the community would affect life satisfaction and affect the community well-being. Consequently, tourism impact studies usually probe residents tourism's perceived impacts on their community and its influences on their life satisfaction and quality of life betterment (Mathew \& Sreejesh, 2017). On the other 
hand, researchers also mentions that if the outcome of tourism development is limited, the residents may refuse to support further tourism development in the destination (Kim et al., 2013; Ridderstaat et al., 2016).

\section{Methodology}

This research constructed a questionnaire which consist of 2 sections. First section is for respondent profile while the second section evaluate the sustainability of EEWC operation based on three main pillars of sustainable development: Economics, Social and Environment. 30 questionnaires was distributed to tourist who stayed at EEWC as well as local people. Out of 30, only 27 questionnaires were returned and completed. Thus, our analysis is based on 27 respondents and the detail outcome can be observed in the following section.

\section{Data Analysis}

The respondent profiles is displayed in Table 1 below. The gender of respondents are quite balance between male and female. Male represents $52 \%$ while female represents $48 \%$ from this survey. The largest group age for the respondent is between 21-39 years old which represent $89 \%$ of total respondent. This group is considered a group with highest purchasing power, those who already enter job markets and spent part of their income for leisure activities. The rest respondents are from $40-49$ years old group (11\%). Next, there is an equal amount of percentage (37\%) between two group of education level which are SPTM/STPM holder and Bachelor/Master/PhD level. The rest percentage belong to the group of respondents with diploma qualification. Next, more than half of the respondent work in private sector $(52 \%)$, followed by government sector (26\%), self employed (11\%) and still not working and student (11\%). Lastly, based on the income level, it is found that 9 out of 27 respondent earned from RM2000 till RM4000, followed by 8 respondent with income level more than RM5000, while there are 5 person each that received income that is lesser than RM5000 and between RM1000 and RM2000. 
Table 1: Respondent Profile

\begin{tabular}{|c|c|c|c|c|c|c|c|c|c|c|c|c|c|c|c|c|c|c|}
\hline \multirow{3}{*}{ BIL } & \multicolumn{18}{|c|}{ SECTION A: RESPONDENT PROFILE } \\
\hline & \multicolumn{2}{|c|}{ GENDER } & \multicolumn{4}{|c|}{ AGE } & \multicolumn{3}{|c|}{ EDUCATION LEVEL } & \multicolumn{5}{|c|}{ JOB } & \multicolumn{4}{|c|}{ INCOME LEVEL } \\
\hline & MALE & FEMALE & $<20$ & $21-39$ & $40-49$ & 50> & SPM/STPM & DIPLOMA & BACHELOR/MASTER/PHD & GOVERNMENT & PRIVATE & own & STUDENT & OTHERS & <RM1000 & RM1000-RM2000 & RM2000-RM4000 $>$ & $>$ RM5000 \\
\hline 1 & & I & & 1 & & & & & I & & & & I & & 1 & & & \\
\hline 2 & & 1 & & 1 & & & I & & & & 1 & & & & & & & 1 \\
\hline 3 & & I & & I & & & & & I & & & & I & & I & & & \\
\hline 4 & & l & & 1 & & & & & I & & l & & & & & & I & \\
\hline 5 & I & & & 1 & & & 1 & & & & l & & & & & l & & \\
\hline 6 & I & & & 1 & & & & l & & & & & I & & I & & & \\
\hline 7 & l & & & l & & & & l & & & & I & & & I & & & \\
\hline 8 & l & & & 1 & & & & I & & & l & & & & & l & & \\
\hline 9 & & 1 & & 1 & & & 1 & & & & 1 & & & & & & I & \\
\hline 10 & l & & & 1 & & & & l & & & l & & & & & & I & \\
\hline 11 & I & & & 1 & & & I & & & & & 1 & & & & & I & \\
\hline 12 & I & & & 1 & & & 1 & & & & I & & & & & & 1 & \\
\hline 13 & I & & & 1 & & & & & I & & I & & & & & & I & \\
\hline 14 & & I & & I & & & & I & & & l & & & & & & I & \\
\hline 15 & & I & & 1 & & & I & & & & & I & & & & & I & \\
\hline 16 & & l & & & 1 & & & & I & 1 & & & & & & & & I \\
\hline 17 & 1 & & & 1 & & & & 1 & & & 1 & & & & & & I & \\
\hline 18 & I & & & 1 & & & & I & & I & & & & & & & & I \\
\hline 19 & & l & & & 1 & & & & 1 & l & & & & & & & & l \\
\hline 20 & I & & & 1 & & & & & I & l & & & & & & & & I \\
\hline 21 & 1 & & & 1 & & & & & 1 & I & & & & & & & & I \\
\hline 22 & l & & & & 1 & & & & l & l & & & & & & & & l \\
\hline 23 & & l & & l & & & & & I & l & & & & & & & & I \\
\hline 24 & & I & & I & & & I & & & & I & & & & & I & & \\
\hline 25 & & I & & I & & & I & & & & I & & & & & I & & \\
\hline 26 & 1 & & & 1 & & & 1 & & & & 1 & & & & I & & & \\
\hline 27 & & 1 & & 1 & & & 1 & & & & 1 & & & & & 1 & & \\
\hline & 14 & 13 & 0 & 24 & 3 & 0 & 10 & 7 & 10 & 7 & 14 & 3 & 3 & 0 & 5 & 5 & 9 & 8 \\
\hline
\end{tabular}

Section B contain assessment of three main pillars of sustainable development which are economics, social and environment. The economics assessment contained 7 questions which is listed below Table 2 . The colours of the scale is as follows:

\section{Scale}

\begin{tabular}{|l|l|}
\hline & Very not satisfied/agreed \\
\hline & Not satisfied/agreed \\
\hline & Uncertain \\
\hline & Satisfied/agreed \\
\hline Very satisfied/agreed \\
\hline
\end{tabular}

Based on the first questions, $67 \%$ satisfied/agreed that EEWS operation help to create more job opportunities to the local people. So far, this chalet contained --- (staff) and they are currently building up more guest room. Thus, this chalet will need to have more workers to help the business run more effectively. Based on question 2, 56\% of total respondent agreed that more local families are benefited from the operation of EEWC business as more additional income that they can earned by providing services such as working part time in this chalet. Next, $37 \%$ of the total responded agreed or satisfied that EEWS operation helped to boost the standard of living of the local communities. The chalet might provide better salary to their workers as their business is expanding over time due to high demand from international and local tourist. Next, about $37 \%$ of the total respondents either not certain or satisfied that EEWS operation managed to reduce the income level gap between the local people. Since this land consist of many island and small communities, the operation of EEWC do help to gives that more changes to work and earn better income for their family through their services. Next, $44 \%$ of the responded agree or satisfied that EEWC operation leads to 
spill over effects through the development of infrastructure around the areas which also benefited the villages that located not far from this chalet. $41 \%$ of the respondent also agreed / satisfied that EEWC operation able to stimulate more economic activities for the community as its helped to create more side jobs to the local people. Lastly, 38\% of the respondents are uncertain if EEWC operation improves the efficiency of its management over time. One reason maybe because this respondent are new customer who visit this chalet and they not yet able to differentiate the efficiency of EEWS management on handling its business.

\section{Section B: Assessment of Sustainability of EEWC operation}

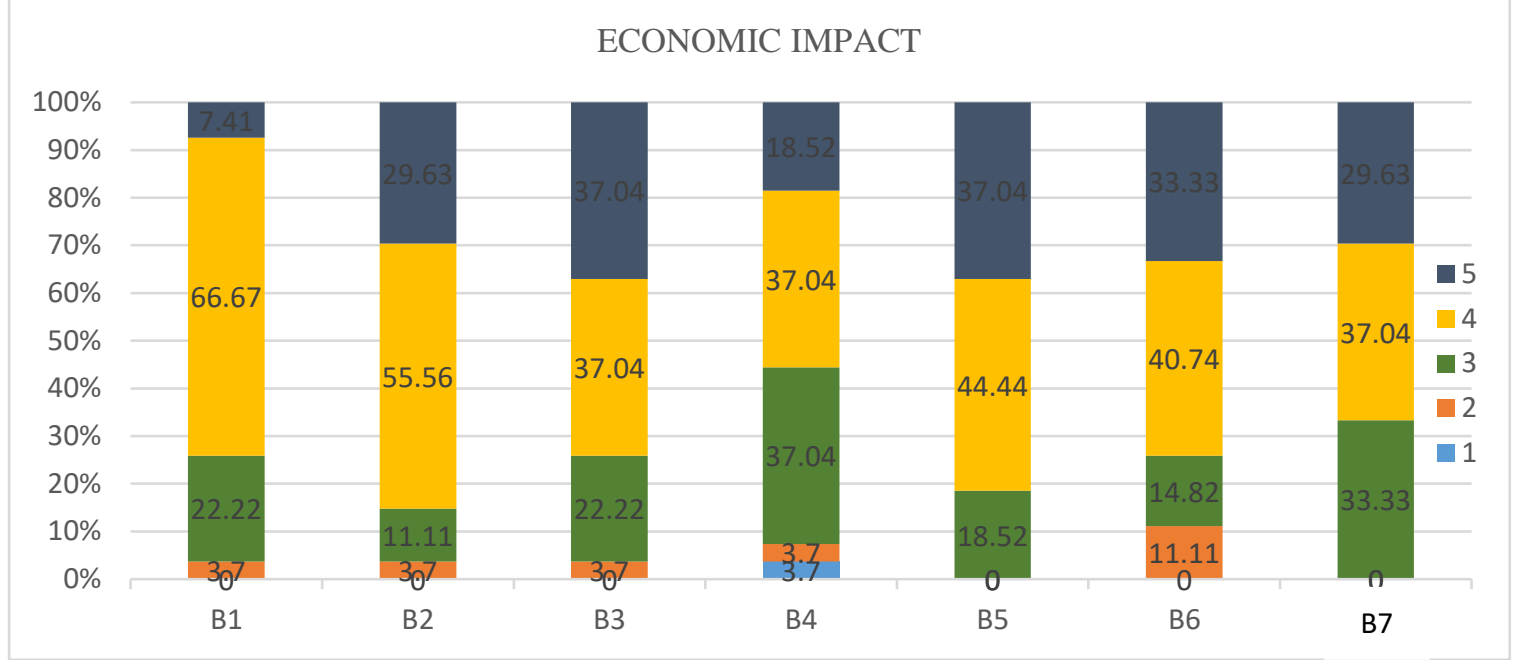

B1: EEWC operation open more job opportunities

B2: EEWC operation help to create additional side income to the local families

B3: BEEWC operation able to increase the standard of living off the local communities

B4: EEWC operation can reduce the income gap between local people

B5: EEWC operation used their profit to developed local areas

B6: EEWC operation helped to stimulate more economic activities for the community

B7: EEWC operation improves the efficiency of the management

The social assessment contained only 5 questions. The elaboration will be emphasised on largest percentage similar to economics and environment assessment. Based on the first question, 56\% respondents satisfied that EEWC operation has helped to change the way of life for the local people. This means that the local people is not only concentrated on traditional activities to earned their income, but they have opportunities to serve EEWC by providing services such as working as receptionist. Next, $33 \%$ of the total respondent are totally not agreed that EEWC has creates disturbance for local people. Local people or even the outsider (tourist0 believed that EEWC creates more benefits to the community than harm. Next, $41 \%$ percent of total respondents are quite uncertain if the EEWC spends their profits to improves the facilities for the tourists who visits their chalet. This outcome shed some valuable information to the management of the chalet to improves further their facilities and so that the tourist will be more happy staying in this chalet; Next, $44.4 \%$ of the total respondent are satisfied that EEWC operations helped to reduces the migration of young people to a larger city. From the observation of tourist, that found that there are still many youngster and adult working as fisherman or working at seaweed farm to earn income and they are basically comfortable working at their own place. Lastly, $41 \%$ of the total respondent believed that EEWC improves the safety of areas and reduce the crime rates as well as the 
social problem. As this chalet able to provide job opportunities, some of the local people now earned better income, and this reduce the crime rates due to lower unemployment rates.

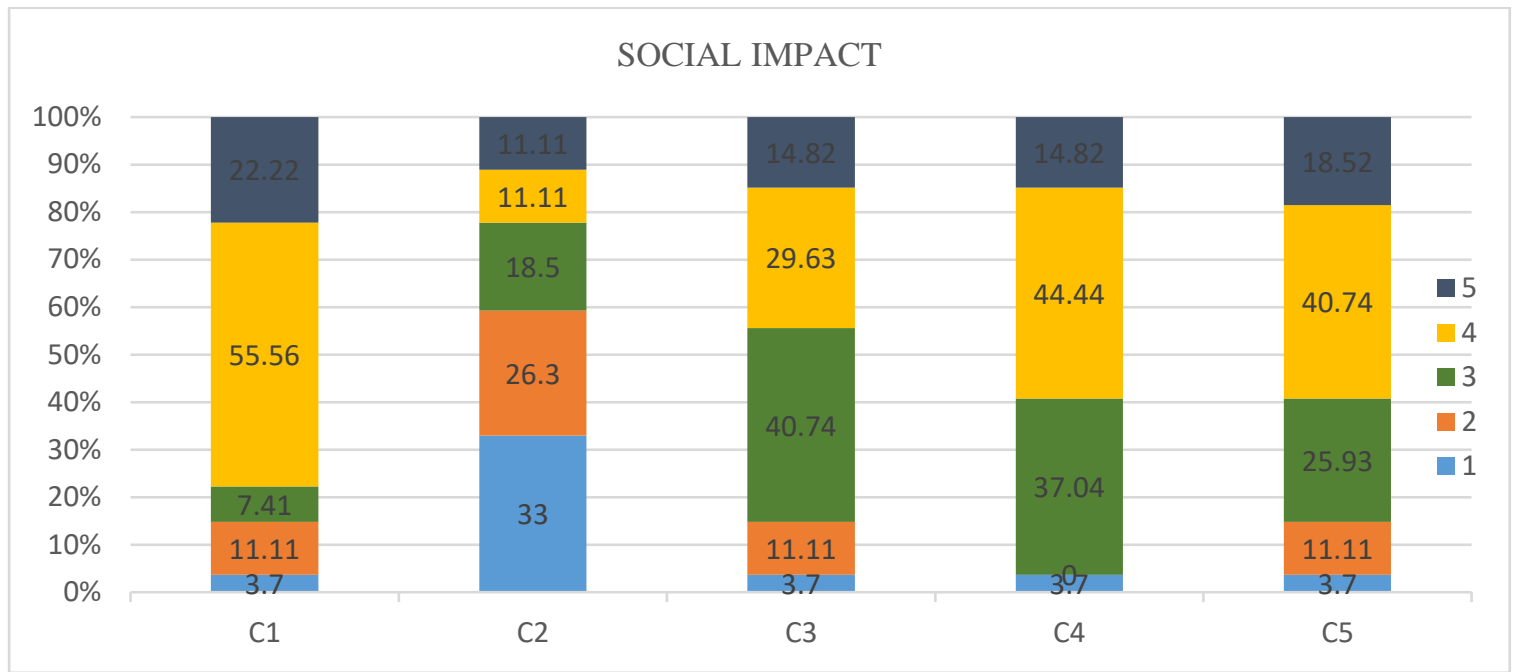

C1: EEWC operation helped to change the way of life for local people

C2: EEWC operation creates disturbances for local people

C3: EEWC operation spend a lot to improves the facilities for tourists

C4: EEWC operation helped to reduces the migration of young people to larger city

C5: EEWC operation improves the safety of the areas and reduces crime rates and social problem

The last assessment is based on environment. There are 8 questions being developed to address the impact of EEWC operation on environmental quality. First, about $37 \%$ of the total respondent are very satisfied with EEWC operation as they witness that this chalet promotes the conservation of environment. Next, $41 \%$ of the total respondent also satisfied that EEWC operations improves the images of the natural surroundings. Perhaps, the chalet landscape at the surface of sea water beautify the scenery of sea. Next, $33 \%$ of total respondent very satisfied that EEWC operations increases the level of cleanness of the surrounding. The management has recruited few local people to clean the surrounding of the chalet to ensure that there is no waste such as plastic bottle new their premises. Next, $33 \%$ respondents are uncertain if the EEWC operation caused air pollution or take serious action on managing their waste and promotes recycling activities in their chalet. This are the point need to be alert by management in the future to improves all these three situations. Next, 33\% of the total respondent are satisfied that the EEWC operations able to protect the fauna such as bird species, as this bird might takes temporary shelter at this chalet. Lastly, about $30 \%$ of the respondent are not agreed that EEWC operations caused water pollution as they find that the chalet do not simply throw their waste into the sea. 


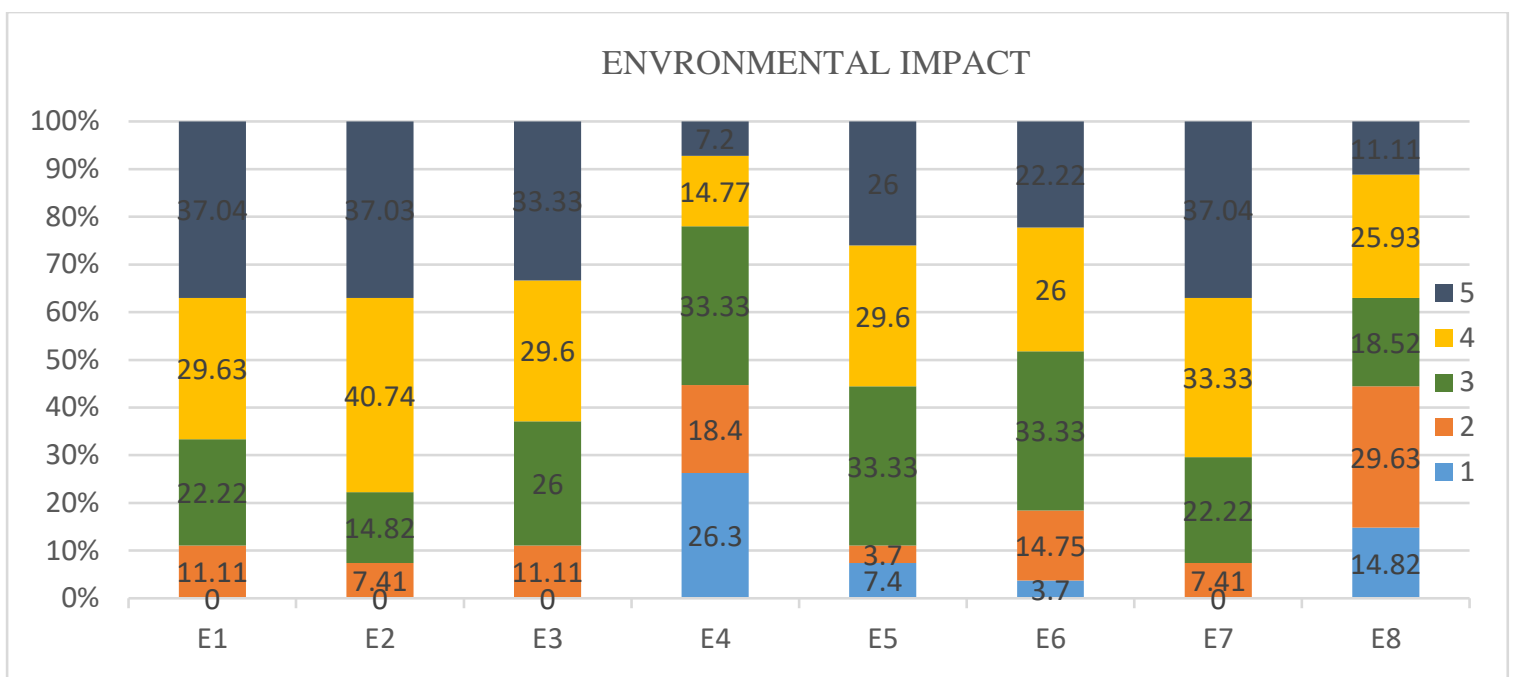

E1: EEWC operation promotes the conservation of environment

E2: EEWC operation improves the images of natural surrounding

E3: EEWC operation increases the level of cleanness of the surrounding

E4: EEWC operation caused air pollution due to increases in boat activities

E5: EEWC operation improves the management of its waste

E6: EEWC operation promotes the activities of recycling

E7: EEWC operation protect the fauna such as bird species

E8: EEWC operation caused water pollution

\section{Conclusion}

This study has found that EEWC operations have positively impacted the three key factors of sustainability: environmental, social and economy. From an environmental standpoint the business operation has promote the conservation of environment by being responsible towards its natural surroundings through its recycling activities and waste management. Socially, EEWC has given opportunities to locals especially to younger generation of employment opportunities which has helped reduce the migration of youths to larger cities and essentially contribute to the development of local industries. As for the economic aspect, the expansion of its business to international tourists has contributed to opportunities for locals to gain side income other than doing their traditional work in fishery. However, this sustainable tourism does not come without challenges. Competitiveness, environmental social issues of sustainable tourism development can be addressed by implementing innovations and fostering sustainable consumption principles by addressing the needs of local communities and dealing with sustainable development priorities of tourism destinations. For future research, the issues of social corporate responsibility, corporate governance and models of business performance can provide valuable inputs to sustainable tourism development if properly addressed by business sectors.

\section{Acknowledgement}

This research publication fees is sponsored by RMI, UiTM Melaka 


\section{References}

Akis, A. (2011). The effects of mass tourism: A case study from Manavgat (Antalya-Turkey). Procedia-Social and Behavioral Sciences, 19, 289-296.

Altinay, L., \& Taheri, B. (2019). Emerging themes and theories in the sharing economy: a critical note for hospitality and tourism. International Journal of Contemporary Hospitality Management. 31(1), 180-193.

Amir, A. F., Ghapar, A. A., Jamal, S. A., \& Ahmad, K. N. (2015). Sustainable tourism development: A study on community resilience for rural tourism in Malaysia. ProcediaSocial and Behavioral Sciences, 168, 116-122.

Aminian, A. (2012). Environmental performance measurement of tourism accommodations in the pilgrimage urban areas: The case of the holy city of Mashhad, Iran. ProcediaSocial and Behavioral Sciences, 35, 514-522.

Andereck, K. L., Valentine, K. M., Knopf, R. C., \& Vogt, C. A. (2005). Residents' perceptions of community tourism impacts. Annals of Tourism Research, 32(4), 1056-1076.

Atkinson, G., Dietz, S., Neumayer, E., \& Agarwala, M. (2014). Handbook of sustainable development: Edward Elgar Publishing.

Basiago, A. D. (1998). Economic, social, and environmental sustainability in development theory and urban planning practice. Environmentalist, 19(2), 145-161.

Bello, F. G., Carr, N., \& Lovelock, B. (2016). Community participation framework for protected area-based tourism planning. Tourism Planning \& Development, 13(4), 469-485.

Berry, S., \& Ladkin, A. (1997). Sustainable tourism: A regional perspective. Tourism Management, 18(7), 433-440.

Blewitt, J. (2014). Understanding sustainable development: Routledge.

Bojanic, D. C., \& Lo, M. (2016). A comparison of the moderating effect of tourism reliance on the economic development for islands and other countries. Tourism Management, 53, 207-214.

Budeanu, A. (2005). Impacts and responsibilities for sustainable tourism: A tour operator's perspective. Journal of Cleaner Production, 13(2), 89-97.

Butler, R. W. (1980). The concept of a tourist area cycle of evolution: Implications for management of resources. Canadian Geographer/Le Géographe canadien, 24(1), 512.

Canteiro, M., Córdova-Tapia, F., \& Brazeiro, A. (2018). Tourism impact assessment: A tool to evaluate the environmental impacts of touristic activities in natural protected areas. Tourism Management Perspectives, 28, 220-227.

Cárdenas, D. A., Byrd, E. T., \& Duffy, L. N. (2015). An exploratory study of community awareness of impacts and agreement to sustainable tourism development principles. Tourism and Hospitality Research, 15(4), 254-266.

Chin, C. (2020, April 27). Malaysia saw more tourists coming to Malaysia in 2019. The Star, Retrieved from https://www.thestar.com.my/lifestyle/travel/2020/04/27/smalltourist-arrivals-growth-to-malaysia-in-2019

Cottrell, S., \& Vaske, J. (2006). A framework for monitoring and modeling sustainable tourism. E-review of Tourism Research, 4(4), 74-84.

Crouch, G. I., \& Ritchie, J. R. B. (1999). Tourism, competitiveness, and societal prosperity. Journal of Business Research, 44(3), 137-152.

Cukier, J. (2002). Tourism employment issues in developing countries: Examples from Indonesia.In R. Sharpley, \& D. J. Telfer (Eds.), Tourism and development, concepts and issues (165-201). Clevedon: Channel View Publications. 
De Jager, A. E., \& Nicolau, M. D. (2020). Opening the door for wider application of the tourism area life cycle model with application to the Rietvlei nature reserve, Tshwane, South Africa. African Journal of Hospitality, Tourism and Leisure, 9(6), 912-929.

Deery, M., Jago, L., \& Fredline, L. (2012). Rethinking social impacts of tourism research: A new research agenda. Tourism Management, 33(1), 64-73.

Emas, R. (2015). The concept of sustainable development: Definition and defining principles. Brieffor GSDR, 2015.

Eusébio, C., Vieira, A. L., \& Lima, S. (2018). Place attachment, host-tourist interactions, and residents' attitudes towards tourism development: The case of Boa Vista Island in Cape Verde. Journal of Sustainable Tourism, 26(6), 890-909.

Forsyth, P., Dwyer, L., Seetaram, N., \& King, B. (2012). Measuring the economic impact of migration-induced tourism. Tourism analysis, 17(5), 559-571.

Gorg, H. (2000). Multinational companies and indirect employment: Measurement and evidence. Applied Economics, 32, 1809-1818.

Green, H., \& Hunter, C. (1992). The environmental impact assessment of tourism development. The environmental impact assessment of tourism development., 29-47.

Goffi, G., Cucculelli, M., \& Masiero, L. (2019). Fostering tourism destination competitiveness in developing countries: The role of sustainability. Journal of Cleaner Production, 209, 101-115.

Gursoy, D., Ouyang, Z., Nunkoo, R., \& Wei, W. (2019). Residents' impact perceptions of and attitudes towards tourism development: A meta-analysis. Journal of Hospitality Marketing \& Management, 28(3), 306-333.

Hall, C.M. \& Lew, A.A. (2009). Understanding and Managing Tourism Impacts: An Integrated Approach. London: Routledge

Hall, C. M. (2019). Constructing sustainable tourism development: The 2030 agenda and the managerial ecology of sustainable tourism. Journal of Sustainable Tourism, 27(7), 1044-1060.

Hall, C. M., \& Lew, A. A. (2009). Understanding and managing tourism impacts: An integrated approach: Routledge.

Hanafiah, M. H., Jamaluddin, M. R., \& Zulkifly, M. I. (2013). Local community attitude and support towards tourism development in Tioman Island, Malaysia. Procedia-Social and Behavioral Sciences, 105, 792-800.

Higgins-Desbiolles, F. (2018). Sustainable tourism: Sustaining tourism or something more? Tourism management perspectives, 25, 157-160.

Hsieh, H.-J., \& Kung, S.-F. (2013). The linkage analysis of environmental impact of tourism industry. Procedia Environmental Sciences, 17, 658-665.

Jordan, E. J., Vogt, C. A., Kruger, L. E., \& Grewe, N. (2013). The interplay of governance, power and citizen participation in community tourism planning. Journal of Policy Research in Tourism, Leisure and Events, 5(3), 270-288.

Jovičić, D. (2011). Socio-cultural impacts of contemporary tourism. Collegium antropologicum, 35(2), 599-605.

Khazaei, A., Elliot, S., \& Joppe, M. (2015). An application of stakeholder theory to advance community participation in tourism planning: The case for engaging immigrants as fringe stakeholders. Journal of Sustainable Tourism, 23(7), 1049-1062.

Kim, K., Uysal, M., \& Sirgy, M. J. (2013). How does tourism in a community impact the quality of life of community residents? Tourism Management, 36, 527-540.

Kuhlman, T., \& Farrington, J. (2010). What is sustainability? Sustainability, 2(11), 3436-3448. 
Kuščer, K., \& Mihalič, T. (2019). Residents' attitudes towards overtourism from the perspective of tourism impacts and cooperation-The case of Ljubljana. Sustainability, 11(6), 1823.

Li, G., Yang, X., Liu, Q., \& Zheng, F. (2014). Destination island effects: A theoretical framework for the environmental impact assessment of human tourism activities. Tourism management perspectives, 10, 11-18.

Ling, L., Jakpar, S., Johari, A., Abdul Rani, N., \& Myint, K. (2011). An evaluation on the attitudes of residents in Georgetown towards the impacts of tourism development. International Journal of Business and Social Science, 2(1), 264-277.

Marafa, L. M. (2008). Integrating sustainable tourism development in coastal and marine zone environment. Études caribéennes(9-10).

Mathew, P. V., \& Sreejesh, S. (2017). Impact of responsible tourism on destination sustainability and quality of life of community in tourism destinations. Journal of Hospitality and Tourism Management, 31, 83-89.

McCombes, L., Vanclay, F., \& Evers, Y. (2015). Putting social impact assessment to the test as a method for implementing responsible tourism practice. Environmental Impact Assessment Review, 55, 156-168.

Meimand, S. E., Khalifah, Z., Zavadskas, E. K., Mardani, A., Najafipour, A. A., \& Ahmad, U. N. U. (2017). Residents' attitude toward tourism development: A sociocultural perspective. Sustainability, 9(7), 1170.

Mihalic, T. (2016). Sustainable-responsible tourism discourse-Towards 'responsustable'tourism. Journal of Cleaner Production, 111, 461-470.

Nunkoo, R. (2016). Toward a more comprehensive use of social exchange theory to study residents' attitudes to tourism. Procedia Economics and Finance, 39, 588-596.

Nunkoo, R., \& Gursoy, D. (2012). Residents' support for tourism: An identity perspective. Annals of Tourism Research, 39(1), 243-268.

Okech, R. N. (2010). Socio-cultural impacts of tourism on World Heritage sites: communities' perspective of Lamu (Kenya) and Zanzibar Islands. Asia Pacific Journal of Tourism Research, 15(3), 339-351.

Oklevik, O., Gössling, S., Hall, C. M., Steen Jacobsen, J. K., Grøtte, I. P., \& McCabe, S. (2019). Overtourism, optimisation, and destination performance indicators: A case study of activities in Fjord Norway. Journal of Sustainable Tourism, 27(12), 1804-1824.

Pan, S.-Y., Gao, M., Kim, H., Shah, K. J., Pei, S.-L., \& Chiang, P.-C. (2018). Advances and challenges in sustainable tourism toward a green economy. Science of the Total Environment, 635, 452-469.

Peters, M., Chan, C.-S., \& Legerer, A. (2018). Local perception of impact-attitudes-actions towards tourism development in the Urlaubsregion Murtal in Austria. Sustainability, 10(7), 2360.

Piuchan, M., Chan, C. W., \& Kaale, J. (2018). Economic and socio-cultural impacts of Mainland Chinese tourists on Hong Kong residents. Kasetsart Journal of Social Sciences, 39(1), 9-14.

Poudel, S., Nyaupane, G. P., \& Budruk, M. (2016). Stakeholders' perspectives of sustainable tourism development: A new approach to measuring outcomes. Journal of Travel Research, 55(4), 465-480.

Pusiran, A. K., \& Xiao, H. (2013). Challenges and Community Development: A Case Study of Homestay in Malaysia. Asian Social Science, 9, 1-17. 
Rasoolimanesh, S. M., Jaafar, M., Kock, N., \& Ramayah, T. (2015). A revised framework of social exchange theory to investigate the factors influencing residents' perceptions. Tourism management perspectives, 16, 335-345.

Ridderstaat, J., Croes, R., \& Nijkamp, P. (2016). The tourism development-quality of life nexus in a small island destination. Journal of Travel Research, 55(1), 79-94.

Risteskia, M., Kocevskia, J., \& Arnaudov, K. (2012). Spatial planning and sustainable tourism as basis for developing competitive tourist destinations. Procedia-Social and Behavioral Sciences, 44, 375-386.

Ritchie, J., Goeldner, C. R., \& Mclntosh, R. W. (2003). Tourism: principles, practices, philosophies: John Wiley \& Son (New Jersey).

Sachs, J. D. (2015). The age of sustainable development: Columbia University Press.

Sandeep, K., \& Vinod, K. (2014). Perception of socio-culture impacts of tourism: A sociological review. International Research Journal of Social Sciences, 3(2), 40-43.

Sinclair-Maragh, G., \& Gursoy, D. (2015). Imperialism and tourism: The case of developing island countries. Annals of Tourism Research, 50, 143-158.

Sokhanvar, A., Çiftçioğlu, S., \& Javid, E. (2018). Another look at tourism-economic development nexus. Tourism Management Perspectives, 26, 97-106.

United Nations General Assembly. (1987). Report of the world commission on environment and development: Our common future. Oslo, Norway: United Nations General Assembly, Development and International Co-operation: Environment.

Uysal, M., Sirgy, M. J., Woo, E., \& Kim, H. L. (2016). Quality of life (QOL) and well-being research in tourism. Tourism Management, 53, 244-261.

Ward, C., \& Berno, T. (2011). Beyond social exchange theory: Attitudes toward tourists. Annals of Tourism Research, 38(4), 1556-1569.

Woo, E., Uysal, M., \& Sirgy, M. J. (2018). Tourism impact and stakeholders' quality of life. Journal of Hospitality \& Tourism Research, 42(2), 260-286.

Wu, H., Kim, S., \& Wong, A. K. F. (2020). Residents' perceptions of desired and perceived tourism impact in Hainan Island. Asia Pacific Journal of Tourism Research, 25(6), 583601. 